\title{
Pelaksanaan Program Layanan Sosial Dan Keterampilan Pada Anak Penyandang Masalah Kesejateraan Sosial (PMKS) Di Panti Sosial
}

\author{
Windy Zulianda, Jalius \\ Universitas Negeri Padang \\ * e-mail: windyzulianda43@gmail.com
}

\begin{abstract}
This research was motivated by the large number of youth with social welfare problems who managed to have the provisions and abilities through social service programs and skills services held by the Panti Sosial Binan Remaja Harapan Kota Padang Panjang, regardless of their slightly problematic social status.This study uses a qualitative approach, with data sources consisting of research subjects, namely the manager of the Harapan Adolescent Social Institution in the City of Padang Panjang, and research informants, namely students at the Panti Sosial Bina Remaja Harapan City of Padang Panjang. This study uses data collection techniques such as interviews, observations, and documentation, using data reduction, data presentation, and drawing conclusions as data analysis techniques, as well as triangulation of sources and methods for data validity techniques. The results of this study indicate that the implementation of the Social Service and Skills Program for Children with Social Welfare Problems (PMKS) at the Panti Sosial Bina Remaja Harapan City of Padang Panjang, namely: the social service program contains entrepreneurship, social and community relations, ethics and behavior change, religious guidance, women's jurisprudence guidance, psychological guidance, art guidance, sports and others. Meanwhile, the skills service program includes sewing and embroidery skills. Overall, the implementation in the field went smoothly, and was in accordance with the expectations of the Padang Panjang City Community Development Center for Youth Hope. The results of the program are also in accordance with what has become the target of the program itself, such as students who have the courage to socialize with local residents by showing good ethics, have been able to produce clothes for everyday use, and some have started to open businesses. sew yourself and even sell the stitches.
\end{abstract}

Keywords: pelaksanaan program, layanan sosial, layanan keterampilan

\section{PENDAHULUAN}

Masalah pendidikan dalam pendidikan sekolah menjadi penyebab pentingnya pentingnya peranan pendidikan non-formal dan masyarakat dalam meminimalisir masalah yang ada. Menurut Sudjana (1989:107), "Peranan pendidikan non-formal terbagi menjadi tiga peranan utama yaitu: sebagai pelengkap, penambah, dan pengganti." 
Berkembangnya permasalahan anak jalanan sudah menjadi fenomena umum bagi suatu negara termasuk Indonesia. Tidak sedikit di persimpangan jalan terdapat anak jalanan. Hal ini jelas sangat mengganggu masyarakat dan pengguna jalan dalam beraktivitas. Oleh karena itu, peran pemerintah dan pihak terkait dalam meminimalisir dan mengatasi permasalahan kesejahteraan sosial anak menjadi kebijakan prioritas agar anak memperoleh perkembangan yang baik.

Pemerintah dan negara dalam melaksanakan tanggung jawabnya seperti yang di maksud dalam Undang-Undang tersebut, memerlukan kebijakan dalam pengembangan nasional teruntuk anak terlantar tersusun, terstruktur, dan berkesinambungan. Selain itu, pola pikir yang berbeda pada setiap organisasi dan perangkat umum mendorong berubahnya pola pikir diantaranya standar-standar merencanakan, standar melaksanakan, standar pengawasan, dan standar-standar pengendalian khususnya di Sumatera Barat.

Salah satu Kota di Sumatera Barat yang menyumbang angka penyandang masalah kesejahteraan sosial adalah Kota Padang Panjang. Menurut data Badan Pusat Statistik Provinsi Sumatera Barat (2020), "Angka penyandang masalah kesejahteraan sosial di Kota Padang Panjang berjumlah 1.332 orang. Jumlah ini jauh menurun jika dibandingkan dengan dua tahun belakang yaitu 2019 dan 2018 yang berjumlah 3.869 dan 4.392.”

Melihat masih terdapatnya beberapa penyadang masalah kesejahteraan sosial di Kota Padang Panjang. Kota Padang Panjang bekerja sama dengan panti-panti sosial di Kota Padang Panjang untuk melaksanakan program layanan sosial dan keterampilan terhadap anak-anak penyandang kesejahteraan sosial guna terpenuhinya kebutuhan perkembangan anak dan dapat mengurangi masalah kesejahteraan sosial di Kota Padang Panjang.

Salah satu panti sosial di Kota Padang Panjang yang melaksanakan program layanan sosial dan keterampilan pada anak penyandang masalah kesejahteraan sosial adalah Bina Remaja Harapan. Panti ini dikhususkan untuk remaja putri yang memiliki penyandang masalah kesejahteraan sosial. Tujuan adanya program ini secara umum adalah untuk mendukung upaya pemerintah dalam meminimalisir angka penyandang masalah kesejahteraan sosial. Secara khusus, untuk menjadikan remaja putri putus sekolah menjadi mandiri, terwujudnya anak remaja putri yang berkualitas, bertanggung jawab, dan sebagai pusat informasi dan pelayanan keterampilan anak penyandang masalah kesejahteraan sosial. Pelaksanaan yang berarti to implement (menerapkan), menyediakan wadah guna melaksanakan, dan memberikan dampak atau akibat pelaksanaan tersebut (Solichin Abdul Wahab, 2004). Serangkaian aktivitas dari langkah lanjutan suatu program yang telah ditetapkan guna sebagai pijakan strategi dalam mencapai sasaran dari program disebut sebagai pelaksanaan (Abdullah, 2014:151). Secara sederhana, pelaksanaan berarti penyesuaian terhadap aktivitas- aktivitas yang akan dilakukan (Usman, 2004:70).

Setelah pelaksanaan dilaksanakan, lalu akan dihasilkan output atau keluaran. Output atau keluaran merupakan hasil aktifitas, pelayanan atau kegiatan dari sebuah program. Output adalah apa yang dihasilkan pada akhir proses. Output menunjukkan apa yang dihasilkan dari aktivitas yang dilakukan. Hasil pendidikan dapat dibagi menjadi dua kategori: konsumsi dan investasi. Dalam konteks ini, Vaizey (1962) menggambarkan konsumsi seperti pembelian roti dan susu sebagai kenikmatan langsung, tetapi investasi seperti pembelian mesin dan pembangunan toko terus menerus untuk produksi jangka panjang. Untuk alasan ini, "investasi terbatas pada satu periode dan kembali ke semua periode yang tersisa" (Becker, 1993). Oleh karena itu, konsumsi dapat diartikan sebagai suatu bentuk keluaran yang dapat dinikmati secara langsung atau langsung dari hasilnya. Berinvestasi adalah suatu bentuk kinerja yang berkelanjutan, yang hasilnya hanya dapat dinikmati secara berkelanjutan dan dalam jangka panjang setelah jangka waktu tertentu.

Berikut akan disajikan hasil penelitian mengenai: (1) pelaksanaan program layanan sosial terhadap anak penyandang masalah kesejahteraan sosial di Panti Sosial Bina Remaja Harapan Kota Padang Panjang; (2) pelaksanaan program layanan keterampilan terhadap anak penyandang 
masalah kesejahteraan sosial di Panti Sosial Bina Remaja Harapan Kota Padang Panjang; (3) output dari program layanan sosial terhadap anak penyandang masalah kesejahteraan sosial di Panti Sosial Bina Remaja Harapan Kota Padang Panjang; (4) output dari program layanan keterampilan terhadap anak penyandang masalah kesejahteraan sosial di Panti Sosial Bina Remaja Harapan Kota Padang Panjang.

\section{METODE}

Penelitian ini menggunakan pendekatan kualitatif, dengan sumber data yang terdiri atas subyek penelitian, yaitu pengelola Panti Sosial Bina Remaja Harapan Kota Padang Panjang, dan informan penelitian, yaitu peserta didik di Panti Sosial Bina Remaja Harapan Kota Padang Panjang. Penelitian ini menggunakan teknik pengumpulan data seperti wawancara, observasi, dan dokumentasi, dengan menggunakan reduksi data, penyajian data, dan penarikan kesimpulan sebagai teknik analisis data, serta triangulasi sumber dan metode untuk teknik keabsahan data.

\section{PEMBAHASAN}

\section{Pelaksanaan Program Layanan Sosial di Panti Sosial Bina Remaja Harapan Kota Padang Panjang}

Berdasarkan temuan penelitian yang diperoleh dari para pengelola dan para informan, peneliti menemukan hasil mengenai pelaksanaan program layanan sosil, yaitu pada layanan sosial terdapat beberapa program yang diberikan pada peserta didik, seperti pembelajaran mengenai lingkungan sosial, masyarakat, kewirausahaan, dan psikologi. Pada program layanan sosial digunakan dengan tatap muka dengan metoe bimbingan individu dan bimbingan kelompok. Namun, yang paling disukai peserta didik ialah metode berkelompok

Program layanan sosial dijadwalkan setiap hari Rabu, Jum'at dan Minggu yang diikuti sebanyak 100 orang anak pada Angkatan II Periode Juli hingga Desember 2021. Pada program ini, pelaksanaan dilakukan di ruang belajar dengan menggunakan metode klasikal (tatap muka), bimbingan perkelompok, dan bimbingan individu. Masing-masing materi belajar disampaikan oleh Instruktur sesuai dengan bidang yang diajar. Insruktur berasal dari berbagai daerah di Sumatera Barat, seperti Kota Padang, Kota Bukittinggi, dan kota Padang Panjang.

Proses belajar mengajar dilakukan oleh Instruktur dengan mengacu kepada mata pelajaran layanan sosial seperti: Wirausaha, Keagamaan, Psikologi, Kesenian, Olahraga, dan lain-lain. Masing-masing mata pelajaran diampu oleh 1 (satu) orang Instruktur. Pelaksanaan program mata pelajaran layanan sosial seperti: (1) olahraga untuk meminimalisir perasaan bosan pada anak asuh, (2) psikologi untuk menguatkan dan meningkatkan jasmani/kemampuan fisik anak asuh, dan (3) keterampilan seni digunakan untuk mengembangkan kesenian dalam diri anak asuh.

\section{Pelaksanaan Program Layanan Keterampilan di Panti Sosial Bina Remaja Harapan Kota Padang Panjang}

Berdasarkan temuan penelitian yang diperoleh dari para pengelola dan para informan, peneliti menemukan hasil mengenai pelaksanaan program layanan keterampilan, yaitu pada layanan keterampilan terdapat dua program yang diberikan pada peserta didik, yaitu menjahit kostum dan membordir. Program tersebut diberikan kepada peserta didik tiap 3 bulan sekali secara bergantian. Jadi, semua peserta didik dapat menguasai kedua program tersebut

Program layanan keterampilan dijadwalkan setiap hari Senin, Selasa, Kamis, dan Sabtu yang diikuti sebanyak 100 orang anak asuh Angkatan II Periode Juli hingga Desember 2021. Program ini diselenggarakan di ruang praktik. Layanan keterampilan yang tersedia yaitu: 
keterampilan menjahit dan membordir. Masing-masing keterampilan ini memiliki ruangan praktik tersendiri guna memudahkan anak asuh untuk berkonsentrasi pada saat praktik keterampilan berlangsung. Pelaksanaan keterampilan dilakukan langsung oleh Instruktur yang berkompeten di bidangnya dan anak asuh secara langsung mempraktikkan teori yang diperoleh dengan alat mesin yang sudah ada.

\section{Output Program Layanan Sosial di Panti Sosial Bina Remaja Harapan Kota Padang Panjang}

Berdasarkan temuan penelitian yang diperoleh dari pengelola dan para informan, serta hasil observasi dan dokumentasi, peneliti menemukan hasil mengenai output pelaksanaan program layanan sosial, yaitu setelah mengikuti bimbingan layanan sosial, anak-anak panti mulai mau bertegur sapa dengan sopan padaan warga. Bahkan mereka melakukan interaksi dengan mengunjungi dan duduk bersama warga, serta berbagi takjil saat bulan Ramadhan

Output atau keluaran adalah hasil dari suatu kegiatan, kegiatan, atau pelayanan suatu program. Output adalah yang dihasilkan pada akhir proses. Output menunjukkan apa yang terjadi dari aktivitas yang dilakukan. Hasil pendidikan dapat dibagi menjadi dua kategori: konsumsi dan investasi. Konsumsi dapat diartikan sebagai suatu bentuk keluaran yang dapat dinikmati secara langsung atau langsung dari hasilnya. Investasi adalah suatu bentuk produksi yang terus menerus, yang hasilnya hanya dapat dinikmati secara berkelanjutan setelah jangka waktu tertentu dan dalam jangka panjang.

Pada program layanan sosial, output yang dihasilkan ialah berupa investasi, yaitu berubahnya sikap dan tingkah laku peserta didik terhadap orang di sekitarnya. Dari semula tidak mau tau dengan warga sekitar, menjadi bukan hanya sekedar tau, tapi sudah ke tahap yang sangat peduli. Bertegur sapa, saling bercerita, bahkan berbagi takjil saat bulan Ramadhan.

\section{Output Program Layanan Keterampilan di Panti Sosial Bina Remaja Harapan Kota Padang Panjang}

Berdasarkan temuan penelitian yang diperoleh dari pengelola dan para informan, serta hasil observasi dan dokumentasi, peneliti menemukan hasil mengenai output pelaksanaan program layanan keterampilan, yaitu hasil yang dikerjakan anak-anak tersebut pada kelas menjahit dan membordir diperuntukkan bagi mereka pribadi dan beberapa anak lulusan panti ini sudah ada yang membuka usaha menjahit sendiri, bahkan sudah mulai menjual hasil jahitannya, seperti masker

Jika pada layanan sosial hanya dihasilkan ouput berupa investasi, lain halnya dengan layanan keterampilan. Pada program layanan keterampilan, output yang dihasilkan dapat berupa investasi dan konsumsi. Output berupa konsumsi, yaitu peserta didik dapat menghasilkan sendiri pakaian dari program menjahit dan membordir yang bisa mereka gunakan sehari-hari. Sedangkan untuk output berupa investasi, yaitu peserta didik sudah ada yang berani membuka usaha menjahit sendiri di kampungnya dan bahkan ada juga yang sudah mulai menjual hasil karyanya.

\section{KESIMPULAN DAN SARAN}

\section{Kesimpulan}

Berdasarkan hasil penelitian dan pembahasan di atas, program layanan sosial dan keterampilan masing-masing memiliki program diantaranya yaitu: program layanan sosial berisikan kewirausahaan, relasi sosial dan kemasyarakatan, etika dan perubahan tingkah laku, bimbingan agama, bimbingan fiqih wanita, bimbingan psikologi, bimbingan kesenian, olahraga dan lain-lain. Sedangkan, program layanan keterampilan meliputi keterampilan menjahit dan membordir. Secara 
keseluruhan, pelaksanaan di lapangan berjalan lancar, dan sesuai dengan yang diharapkan pihak Panti Sosial Bina Remaja Harapan Kota Padang Panjang. Hasil dari program tersebut pun sesuai dengan yang sudah menjadi target dari program itu sendiri, seperti peserta didik yang sudah berani bersosialisasi dengan warga sekitar dengan menunjukkan etika yang baik, sudah bisa menghasilkan baju untuk dipakai sehari-hari, dan sudah ada yang memulai untuk membuka usaha menjahit sendiri bahkan juga menjual hasil jahitannya.

\section{Saran}

Saran yang dapat penulis berikan adalah terkhusus dalam pelaksanaan kegiatan-kegiatan program layanan sosial dan keterampilan perlu dipantau tingkat keterlaksanaannya secara kontinue. Selain itu, pihak panti perlu melakukan inovasi baru bagi anak asuh dalam belajar, seperti memberikan hadiah bagi anak asuh yang tidak pernah bermasalah, sehingga anak asuh menjadi semakin termotivasi dan lebih giat untuk belajar.

\section{DAFTAR PUSTAKA}

Andika, Y., \& Sunarti, V. (2018). Hubungan antara Komunikasi Keluarga dengan Kemampuan Bicara Anak Usia Dini Desa Rambai. Spektrum: Jurnal Pendidikan Luar Sekolah (PLS), 1(4), 545. https://doi.org/10.24036/spektrumpls.v1i4.101656

Arikunto, S. (2016). Prosedur Penelitian: Suatu Pendekatan Praktik. Jakarta: Rineka Cipta.

Astuti, T. (2018). Hubungan Pola Komunikasi Orangtua Terhadap Perkembangan Berbicara Anak di Taman Kanak-Kanak. JRTI: Jurnal Riset Tindakan Indonesia, 3(2), 88-95.

Calista, R., Yeni, I., \& Pransiska, R. (2019). Hubungan Pola Komunikasi Orang Tua terhadap Perkembangan Berbicara Anak di Raudhatul Athfal Ikhlas Gunung Pangilun Padang. Journal Pendidikan Tambusai, 3(6), 1632-1638.

Darmawan, C. (2017). Komunikasi dan Interaksi Keluarga. Pendidikan Keluarga, 3(1), 1-19.

Gunawan, A. (2016). Kamus Praktis Bahasa Indonesia. Surabaya: Kartika.

Hartati, S. (2017). Perkembangan Belajar pada Anak Usia Dini. Jakarta: Departemen Pendidikan Nasional.

Hasanah, N., \& Sugito, S. (2020). Analisis Pola Asuh Orang Tua terhadap Keterlambatan Bicara pada Anak Usia Dini. Jurnal Obsesi : Jurnal Pendidikan Anak Usia Dini, 4(2), 913. https://doi.org/10.31004/obsesi.v4i2.456

Hurlock, E. (2014). Perkembangan Anak: Alih Bahasa Oleh Soedjarmo \& Istiwidayanti. Retrieved from https://jurnal.uisu.ac.id/index.php/Bahastra/article/viewFile/1137/898

Ismaniar, \& Hazizah, N. (2019). Buku Ajar Pelatihan Kreativitas Deu-coupage bagi Pendidik PAUD. https://doi.org/10.31227/osf.io/6urtg

Ismaniar, I. (2020). Model Pengembangan Membaca Awal Anak: Berbasis Optimalisasi Pemanfaatan Lingkungan Keluarga. Padang: Jurusan Pendidikan Luar Sekolah.

D dalam Penerapan Model Environmental Print Berbasis Keluarga untuk Meningkatkan Kemampuan Membaca Awal Anak. KOLOKIUM: Jurnal Pendidikan Luar Sekolah, 6(2), 93-100. https://doi.org/10.24036/kolokium-pls.v6i2.9

Kurniasari, L., \& Sunarti, S. (2019). Early detection of speech delay and family factors. Journal of Public Health in Africa, 10(1). Retrieved from https://publichealthinafrica.org/index.php/jphia/article/download/1212/532/

Madyawati, L. (2016). Strategi Pengembangan Bahasa pada Anak. Jakarta: Kencana Prenada Media Group.

Nurbiana, D. D. (2019). Metode Pengembangan Bahasa. Jakarta: Universitas Terbuka.

Rofiq, A., \& Nihayah, I. (2018). Komunikasi Sebagai Modal Utama Orang Tua Dalam Pembentukan Kepribadian Anak. OSF Preprint, 1-15. https://doi.org/10.31219/osf.io/2cxyt

Shaumi, A. M., \& Ismaniar, I. (2020). The Relationship Between the Family Communication and Talking Early Children at the Pisang Village Kinali Districts Pasaman Barat. SPEKTRUM: 
Windy Zulianda, Jalius

Jurnal Pendidikan Luar Sekolah (PLS), $\quad 8(4), \quad 515$. https://doi.org/10.24036/spektrumpls.v8i4.110145

Soetjiningsih, C. H. (2016). Perkembangan Anak. Jakarta: Prenada Media Group.

Subqi, I. (2016). Pola Komunikasi Keagamaan dalam Membentuk Kepribadian Anak. 1(2), 165180.

Sugiyono. (2017). Metode Penelitian Kuantitatif, Kulaitatif, dan R\&B. Bandung: Alfabeta.

Sumaryanti, L. (2017). Peran Lingkungan Terhadap Perkembangan Bahasa Anak. Jurnal MUADDIB, 7(1), 72-89.

Suranto. (2016). Komunikasi Interpersonal. Yogyakarta: Graha Ilmu.

Susanto, A. (2016). Perkembangan Anak Usia Dini Pengantar dalam Berbagai Aspeknya. Jakarta: Kencana Perdana Media Group.

Susanto, A. (2017). Teori Belajar \& Pembelajaran. Jakarta: Prenada Media Group.

Yulianda, A. (2019). Faktor-Faktor Yang Mempengaruhi Keterlambatan Berbicara Berbicara Pada Anak Balita. Jurnal Pendidikan Bahasa Dan Sastra Indonesia, 3(2), 12-16. 